\title{
Short communication: Effects of drying and analytical methods on nitrogen concentrations of feeds, feces, milk, and urine of dairy cows
}

\author{
D. L. Morris, A. W. Tebbe, W. P. Weiss, and C. Lee* \\ Department of Animal Sciences, Ohio Agricultural Research and Development Center, The Ohio State University, Wooster 44691
}

\begin{abstract}
Nitrogen concentrations in feeds, feces, milk, and urine samples were measured using 2 analytical methods following different drying procedures. Ten samples of corn silage, alfalfa silage, and concentrates collected from 2017 to 2018 at Krauss Dairy Research Center, The Ohio State University (Wooster), were used. A 4-d total collection digestion trial provided fecal samples from 10 cows (1 sample/cow), and another 10 cows were used to collect milk samples (1 sample/cow) and spot urine samples (1 sample/cow). Spot urine samples were acidified immediately to $\mathrm{pH}<3.0$ when collected. Feed samples were oven dried $\left(55^{\circ} \mathrm{C}\right)$ or lyophilized and analyzed using the Kjeldahl (KJ; copper sulfate as a catalyst) method and a combustion method (elemental analyzer; EA). Feces, urine, and milk samples were analyzed for $\mathrm{N}$ using the following methods: (1) fresh samples by KJ (referred to as wet KJ), (2) lyophilization (urine and milk for $8 \mathrm{~h}$; feces for $120 \mathrm{~h}$ ) followed by EA (LYO-EA), and (3) oven drying (milk and urine for $1 \mathrm{~h}$; feces for $72 \mathrm{~h}$ at $55^{\circ} \mathrm{C}$ ) followed by EA (ODEA). Additionally, changes in $\mathrm{N}$ content of acidified urine at $-20^{\circ}$ over $180 \mathrm{~d}$ of storage were examined. Nitrogen concentrations in corn silage, alfalfa silage, and concentrates were greater for EA by $6.1,4.8$, and $8.3 \%$, respectively, compared with KJ. Analysis of dried samples via EA compared with wet KJ resulted in lower fecal $\mathrm{N}$ content (27.8 vs. $29.3 \mathrm{~g} / \mathrm{kg}$ of DM). Nitrogen concentration in fecal samples via KJ after lyophilization was lower by $5 \%$ compared with wet KJ but did not differ from LYO-EA, suggesting that $\mathrm{N}$ losses occurred during drying. Nitrogen determination with EA after drying of samples resulted in greater milk N (5.70 vs. $5.50 \mathrm{~g} / \mathrm{kg})$ and urinary N (9.16 vs. $9.06 \mathrm{~g} / \mathrm{kg}$ ) content compared with wet KJ. However, drying method (i.e., lyophilization vs. oven drying) did not affect $\mathrm{N}$ content of milk, urine, or feces. The use of
\end{abstract}

Received January 6, 2019.

Accepted February 20, 2019.

*Corresponding author: Lee.7502@osu.edu
EA resulted in lower percentage deviation of $\mathrm{N}$ content from duplicate sample assays for most samples (no difference was found for concentrate and fecal N), suggesting that EA was more precise than KJ. In conclusion, drying of feces caused $\mathrm{N}$ losses regardless of drying methods. For urine and milk samples, if drying is necessary (i.e., EA), oven drying at $55^{\circ} \mathrm{C}$ can be used rather than lyophilization. The $\mathrm{N}$ content was greater in feeds, milk, and urine when determined with EA versus KJ. In addition, $\mathrm{N}$ content in acidified and undiluted urine at $-20^{\circ}$ changed and should be analyzed within $90 \mathrm{~d}$ of storage. The results in the current study, however, did not account for laboratory-to-laboratory variation.

Key words: combustion method, Kjeldahl, oven drying, lyophilization

\section{Short Communication}

The Kjeldahl (KJ) method has been the most widely used method for determination of $\mathrm{N}$ in samples collected from animal nutrition studies. The combustion method (elemental analyzer; EA) has increased in popularity for $\mathrm{N}$ analysis because it is quicker and less labor intensive and decreases harmful chemical usage (i.e., $\mathrm{H}_{2} \mathrm{SO}_{4}, \mathrm{NaOH}$ ). The $\mathrm{N}$ fractions measured by KJ and EA differ slightly. Although EA quantifies total N in all fractions, the recovery of some non-amino $\mathrm{N}$ (e.g., nitrate and nucleic acids) by KJ is not 100\% (Simonne et al., 1998; Jung et al., 2003), which may cause a slight difference in sample $\mathrm{N}$ contents (i.e., feeds, feces, milk, and urine) between KJ and EA. In addition, $\mathrm{N}$ analysis using EA may require drying of samples before sample analysis, which may result in $\mathrm{N}$ volatilization, whereas KJ does not require drying of samples. Oven drying (OD) of cattle feces resulted in $\mathrm{N}$ losses ranging from 4.1 to $11.9 \%$ (Gallup and Hobbs, 1944; Colovos et al., 1957; Bratzler and Swift, 1959). Lyophilization (LYO) is thought to decrease risk of $\mathrm{N}$ loss because samples remain frozen throughout the drying process, and $\mathrm{N}$ loss is positively associated with temperature (Hristov et al., 2011). Although OD is more convenient and faster in drying samples than LYO, LYO may be a preferred drying method over OD to avoid potential $\mathrm{N}$ losses. 
The form of $\mathrm{N}$ that potentially becomes volatilizable during OD of samples would be urea (if hydrolyzed) or inorganic $\mathrm{N}$, and these forms of $\mathrm{N}$ are contained in samples of feeds, milk, feces, and urine from dairy cows. Variable losses of $\mathrm{N}$ from samples during processing could affect determination of $\mathrm{N}$ excretion, digestibility, and balance in dairy cows and thus limit accuracy in estimating $\mathrm{N}$ metabolism and utilization responses to various dietary modifications. To our knowledge, no information is available on differences in $\mathrm{N}$ concentrations in samples derived from dairy nutrition studies when determined after different drying methods followed by $\mathrm{N}$ analysis using KJ or EA. Therefore, this study was designed to examine effects of drying and $\mathrm{N}$ determination methods of various dairy samples on sample $\mathrm{N}$ concentrations.

Samples of corn silage, alfalfa silage, and concentrates (grain mix containing mainly corn grain, soybean meal, soybean hulls, and vitamin and mineral supplements) from dairy nutrition experiments conducted at The Ohio State University (Wooster) from 2017 to 2018 (10 samples each) were used. Nitrogen concentrations of the feed samples were compared only for $\mathrm{N}$ analytical methods (i.e., KJ vs. EA) and not drying method (i.e., OD vs. LYO) because OD is the standard drying method for forages and feeds in dairy nutrition research and no or minimal $\mathrm{N}$ losses were expected due to low $\mathrm{pH}$ in silages (pH 3 to 5 ) and dryness of concentrates. Heberer et al. (1985) and Pelletier et al. (2010) observed no difference in $\mathrm{N}$ concentration in various feeds and fresh forages (timothy and alfalfa) when determined after OD $\left(55^{\circ} \mathrm{C}\right)$ or FD. Deinum and Maassen (1994) observed no differences in $\mathrm{N}$ concentration in various forages including corn silage when samples were dried by $\mathrm{OD}\left(50^{\circ} \mathrm{C}\right)$ or $\mathrm{FD}$. However, one study by Alomar et al. (1999) reported a decrease in CP concentration by $5 \%$ when pasture silage was oven dried at $65^{\circ} \mathrm{C}$ versus FD.

Samples of milk, urine, and feces were collected from other experiments. Fecal samples were obtained from 10 cows (average $\pm \mathrm{SD}$; DIM $=157 \pm 39$; milk yield $=$ $40.7 \pm 7.2 \mathrm{~kg}$ ) during a digestibility experiment (Tebbe et al., 2018) in which daily fecal excretion was quantified over a 4-d total collection period (Weiss et al., 2009). The basal diet fed to cows consisted of about $34 \%$ corn silage, $22 \%$ alfalfa silage, $18 \%$ ground corn, $13 \%$ soybean meal, $8 \%$ soyhulls, and $5 \%$ minerals and vitamins with a $\mathrm{CP}$ of $16.8 \%$ on a DM basis. Although milk and urine samples were also collected during the total collection of feces, the milk and urine samples were not used in the current experiment because the samples were frozen and thawed several times and had been stored in a freezer for months. Our investigation
Table 1. Nitrogen stability in urine samples over $180 \mathrm{~d}$ at $-20^{\circ} \mathrm{C}$ and effects of thawing of urine sample during storage on $\mathrm{N}$ concentration ${ }^{1,2}$

\begin{tabular}{ccc}
\hline \multirow{2}{*}{ Item } & $\begin{array}{c}\text { Urine } \mathrm{N}, \\
\mathrm{g} / \mathrm{kg}\end{array}$ & $P$-value \\
\hline
\end{tabular}

Duration of urine storage, $\mathrm{d}$

$\begin{array}{ll}0 & 9.10^{\mathrm{a}}(2.43) \\ 30 & 8.99^{\mathrm{a}}(2.53) \\ 60 & 9.02^{\mathrm{a}}(2.46) \\ 90 & 8.97^{\mathrm{a}}(2.31) \\ 180 & 8.56^{\mathrm{b}}(2.49) \\ 180{\text { (thawed once on d } 30)^{4}}^{\mathrm{c}} & 8.18^{\mathrm{c}}(2.35) \\ \text { SEM } & 0.702\end{array}$

Duration 0.04

180 vs. 180 thawed 0.04

Linear $<0.01$

Quadratic $\quad 0.35$

${ }^{\mathrm{a}-\mathrm{c}}$ Within a row, means without a common superscript letter $\operatorname{differ}(P$ $\leq 0.05)$.

${ }^{1}$ Urine samples were obtained from 12 cows ( 1 sample/cow), and 4 subsamples for each were frozen. Then, $\mathrm{N}$ concentrations were determined using an elemental analyzer after oven drying at $55^{\circ}$ for $1 \mathrm{~h}$.

${ }^{2}$ Numbers in parentheses represent SD within day (i.e., cow-to-cow variation).

${ }^{3}$ Duration $=$ storage duration effect among $0,30,60,90$, and $180 \mathrm{~d} ; 180$ vs. 180 thawed $=180 \mathrm{~d}$ vs. $180 \mathrm{~d}$ (thawed once on d 30). Polynomial contrasts are for storage duration excluding the 180-d thawed samples. Cubic and quartic effects were not shown due to insignificance.

${ }^{4}$ Samples $(\mathrm{n}=12)$ that were thawed and analyzed for $\mathrm{N}$ on $\mathrm{d} 30$ of storage were refrozen at $-20^{\circ} \mathrm{C}$ and reanalyzed on d 180 of storage.

about changes in urinary $\mathrm{N}$ concentration during the storage of urine samples at $-20^{\circ} \mathrm{C}$ is shown in Table 1 . From this investigation, urine samples were collected from 12 cows $(\mathrm{n}=12)$ and each sample was acidified with $2 \mathrm{M} \mathrm{H}_{2} \mathrm{SO}_{4}$ to maintain $\mathrm{pH}<3.0$ (average $\pm \mathrm{SD}$; $2.19 \pm 0.35$ ). To determine the effect of storage length on $\mathrm{N}$ concentration, urine samples were split into 5 microcentrifuge tubes and then stored at $-20^{\circ} \mathrm{C}$ until analysis.

One tube at a time of $30,60,90$, and $180 \mathrm{~d}$ of storage was thawed immediately before analysis (samples were dried at $55^{\circ} \mathrm{C}$ for $1 \mathrm{~h}$ and analyzed for $\mathrm{N}$ using $\mathrm{EA}$ ). The results indicated that urinary $\mathrm{N}$ content determined by EA after OD linearly decreased $(P<0.01)$ over time when stored at $-20^{\circ} \mathrm{C}$ (especially on d 180 of storage). In addition, during $180 \mathrm{~d}$ of storage at $-20^{\circ} \mathrm{C}$, samples that had been thawed once previously were lower in $\mathrm{N}$ content (8.16 vs. $8.56 \mathrm{~g} / \mathrm{kg} ; P=0.04$ ) compared with samples without thawing. The decrease in $\mathrm{N}$ content of urine during storage and when thawed previously during storage likely occurred due to crystallization (e.g., magnesium ammonium phosphate; Albasan et al., 2003) rather than $\mathrm{N}$ volatilization due to acidification and the rapid drying process of urine (see the discussion later). All the urine samples in the current study were acidified without dilution with distilled water, which 
may have caused crystallization or increased the degree of crystallization in urine.

Fresh milk and urine samples were collected from 10 cows (average $\pm \mathrm{SD} ; \mathrm{DIM}=203 \pm 27$; milk yield $=$ $26.7 \pm 5.2 \mathrm{~kg}$ ). The basal diet fed to the cows contained $37 \%$ corn silage, $20 \%$ alfalfa silage, $24.3 \%$ ground corn, and $11.9 \%$ soybean meal with a $\mathrm{CP}$ of $16.4 \%$ on a DM basis. Milk samples were collected for 4 consecutive milkings $(2 \mathrm{~d})$, stored at $4^{\circ} \mathrm{C}$, and composited within cow immediately after the last sample collection. Spot urine samples were collected approximately $4 \mathrm{~h}$ postfeeding and acidified with $2 M \mathrm{H}_{2} \mathrm{SO}_{4}$ to maintain $\mathrm{pH}$ $<3.0$ (average $\pm \mathrm{SD} ; 2.19 \pm 0.35$ ).

Individual samples of corn silage and alfalfa silage were oven dried at $55^{\circ}$ for $72 \mathrm{~h}$ or lyophilized $(120 \mathrm{~h}$ at $<-40^{\circ} \mathrm{C}$ and $<10,000 \mathrm{~Pa}$; FreezeZone 6 , Labconco Corp., Kansas City, MO). Dried samples and concentrates were ground through a 1-mm sieve (Wiley mill; Thomas Scientific, Swedesboro, NJ). All ground samples were measured for DM at $100^{\circ} \mathrm{C}$ overnight (about $16 \mathrm{~h}$ ) and $\mathrm{N}$ concentration by KJ or EA. For $\mathrm{N}$ analysis using EA, all ground samples were pulverized (MM200; Retsch, Haan, Germany) before applying to EA.

Composite milk, urine, and fecal samples were analyzed for $\mathrm{N}$ by the following methods: (1) subsamples of fresh composite milk, urine, and feces were assayed within $24 \mathrm{~h}$ by KJ (referred to as wet KJ; AOAC International, 2000, method 984.13), where copper sulfate pentahydrate was used as a catalyst; (2) subsamples were frozen $\left(-20^{\circ} \mathrm{C}\right)$ overnight, lyophilized (urine and milk for $8 \mathrm{~h}$; feces for $120 \mathrm{~h}$ at $<-40^{\circ} \mathrm{C}$ and $<10,000$ $\mathrm{Pa}$; FreezeZone 6, Labconco Corp.), and applied to EA (LYO-EA; Flash 2000; Thermo Fisher Scientific, Waltham, MA); or (3) subsamples were oven dried (milk and urine for $1 \mathrm{~h}$ and feces for $72 \mathrm{~h}$ at $55^{\circ} \mathrm{C}$ ) and applied to EA (OD-EA). For milk and urine, about 30 mg was weighed (XP6 Micro Balance; Mettler-Toledo LLC, Columbus, OH) into $5-\times 9-\mathrm{mm}$ tin capsules (Costech, Valencia, CA) and then oven dried or lyophilized. Dried milk and urine samples were applied to EA for $\mathrm{N}$ determination. Dried feces (i.e., LYO or OD) were ground to pass a 1-mm screen (Wiley mill; Arthur H. Thomas Co., Philadelphia, PA), pulverized (MM200; Retsch), and weighed (4-5 mg) into the same $5-\times 9$-mm tin capsules. Tin capsules containing dried samples were then applied to EA for $\mathrm{N}$ analysis (combustion and reduction ovens were maintained at 980 and $650^{\circ} \mathrm{C}$, respectively, and $\mathrm{He}$ at $100 \mathrm{~mL} / \mathrm{min}$ was used as a carrier gas). Because $\mathrm{N}$ analysis by KJ does not require drying of samples, fresh urine, milk, and feces were assayed by KJ (DM of feces was determined for $24 \mathrm{~h}$ at $100^{\circ} \mathrm{C}$ ). In addition, lyophilized feces were further analyzed by KJ (LYO-KJ) to determine dif- ferences in $\mathrm{N}$ content between analytical methods (i.e., wet KJ vs. LYO-KJ and LYO-KJ vs. LYO-EA; see later discussion).

All individual samples were assayed in duplicate, and acetanilide (112933; MilliporeSigma, St. Louis, MO) was used as a reference for KJ and EA. The sample size for KJ assays was about 1, 5, 3, and $2 \mathrm{~g}$ (as-is basis) for feeds, feces, milk, and urine, respectively. The recovery of acetanilide-N was between 98 and $101 \%$ for both KJ and EA. To determine precision of analytical methods, percentage deviation (PD) was calculated between duplicate samples A and B:

$$
(\mathrm{A}-\mathrm{B}) \text { /average of } \mathrm{A} \text { and } \mathrm{B} \times 100,
$$

where A is the greater concentration of the duplicate assays of individual samples. If PD was greater than $5 \%$, the samples were reanalyzed to reduce the contribution of sampling error; that is, variation was assumed partly as a result of sampling error (e.g., failure of representative subsampling when samples were weighed out for applying to KJ or EA), not analytical error. Therefore, PD of all samples was less than $5 \%$.

Data $(\mathrm{n}=12)$ in Table 1 were analyzed using the MIXED procedure of SAS (version 9.4; SAS Institute Inc., Cary, NC) with a model including sample (i.e., cow) as random effect and day as fixed effect. Day was applied as repeated measurement with sample as a subject with autoregressive first-order covariate structure. The coefficients for unequal-interval linear, quadratic, cubic, and quartic effects were obtained using the IML procedure of SAS. All data in Tables 2 and 3 were analyzed using the MIXED procedure of SAS with the fixed effect of method (KJ or EA for feeds and wet KJ, OD-EA, or LYO-EA for feces, milk, and urine) and the random effect of sample. Method was analyzed as a repeated measure with an autoregressive first-order covariate structure. Denominator degrees of freedom for all models were calculated using the Kenward-Roger option. For feces, milk, and urine, orthogonal contrasts were used to compare the effect of analytical method (wet KJ vs. LYO-EA and OD-EA) and drying method (LYO-EA vs. OD-EA). The same model was used to compare $\mathrm{N}$ concentrations among wet KJ, LYO-KJ, and LYO-EA (see the footnote of Table 2).

Feed N concentrations were lower $(P<0.01)$ when determined by KJ compared with EA (Table 2). Corn silage, alfalfa silage, and concentrates were lower in $\mathrm{N}$ concentration by $6.1,4.8$, and $8.3 \%$, respectively, for KJ compared with EA. Percentage deviation was generally lower $(P \leq 0.08)$ for EA compared with KJ (i.e., corn and alfalfa silage) but was not different $(P=0.30)$ for concentrates. A previous study summarized differences 
Table 2. Nitrogen concentrations of feeds, feces, milk, and urine and their SD when determined from wet, lyophilized (LYO), or oven-dried (OD; $55^{\circ} \mathrm{C}$ ) samples using the Kjeldahl $(\mathrm{KJ})$ method or an elemental analyzer (EA)

\begin{tabular}{|c|c|c|c|c|c|c|c|c|c|}
\hline \multirow[b]{2}{*}{ Item } & \multirow[b]{2}{*}{ KJ } & \multirow[b]{2}{*}{$\mathrm{SD}^{1}$} & \multirow[b]{2}{*}{ EA } & \multirow[b]{2}{*}{$\mathrm{SD}$} & & & \multirow[b]{2}{*}{ SEM } & \multicolumn{2}{|c|}{$P$-value ${ }^{2}$} \\
\hline & & & & & & & & KJ-EA & LYO-OD \\
\hline Corn silage & 13.2 & 0.81 & 14.0 & 0.67 & & & 0.24 & $<0.01$ & \\
\hline $\mathrm{PD}^{3}$ & 2.70 & 2.09 & 1.37 & 0.94 & & & 0.512 & 0.08 & \\
\hline Alfalfa silage & 29.0 & 2.61 & 30.4 & 3.09 & & & 0.90 & $<0.01$ & \\
\hline $\mathrm{PD}$ & 2.83 & 1.35 & 0.91 & 0.96 & & & 0.369 & $<0.01$ & \\
\hline $\mathrm{PD}$ & Wet KJ & $\mathrm{SD}$ & LYO-EA & $\mathrm{SD}$ & OD-EA & $\mathrm{SD}$ & & & \\
\hline Fecal $N^{4} \mathrm{~g} / \mathrm{kg}$ of DM & 29.3 & 2.34 & 27.6 & 2.30 & 27.9 & 1.60 & 0.67 & $<0.01$ & 0.78 \\
\hline $\mathrm{PD}$ & 1.78 & 1.45 & 0.98 & 0.69 & 2.09 & 1.23 & 0.368 & 0.61 & 0.06 \\
\hline Milk N, g/kg & 5.50 & 0.33 & 5.70 & 0.29 & 5.69 & 0.31 & 0.097 & $<0.01$ & 0.72 \\
\hline $\mathrm{PD}$ & 2.41 & 1.55 & 0.46 & 0.69 & 0.59 & 0.59 & 0.328 & $<0.01$ & 0.78 \\
\hline
\end{tabular}

${ }^{1}$ Average analytical result over the 10 samples.

${ }^{2}$ KJ-EA (i.e., wet vs. dried) = wet KJ vs. the average of LYO-EA and OD-EA; LYO-OD = LYO-EA vs. OD-EA.

${ }^{3}$ LSM of percentage deviations [(larger number - smaller number)/average $\times 100$ ] of duplicate analysis of each sample.

${ }^{4}$ To determine the factor that causes the significant difference between KJ and EA, further analysis was conducted with the same statistical model used for feces, milk, and urine in this table. Fecal samples were lyophilized and followed by N analysis using KJ (LYO-KJ), where N concentration of feces for LYO-KJ was $27.7 \mathrm{~g}$ of $\mathrm{N}$ in fecal DM $(\mathrm{kg})$. Wet KJ vs. LYO-KJ, $P<0.01 ;$ LYO-KJ vs. LYO-EA, $P=0.83$.

in feed or food $\mathrm{N}$ concentrations between KJ and EA (Simonne et al., 1997) where the ratio of $\mathrm{N}$ from KJ to $\mathrm{N}$ from EA ranged from 0.93 to 1.00 . In our study, the ratio between $\mathrm{KJ}$ and $\mathrm{EA}$ was within this range (0.94 for corn silage, 0.95 for alfalfa silage, and 0.92 for concentrates). Jung et al. (2003) examined various soy products, and the ratio of $\mathrm{N}$ content between $\mathrm{KJ}$ and EA was from 0.95 (tofu) to 1.03 (protein extract), where soybeans $(0.97)$ and defatted soy flakes (0.97) had greater $\mathrm{N}(P<0.05)$ when determined by EA versus KJ. However, no difference in $\mathrm{N}$ concentrations between KJ and EA for distillers dried grains with solubles was observed (Thiex, 2009). The discrepancy between the methods is not fully understood. Nitrate is a known form of $\mathrm{N}$ that causes differences between the 2 methods. However, nitrate concentration of feeds is usually small and cannot fully explain the difference between the 2 methods (Simonne et al., 1998). Therefore, more studies to identify the factors causing the discrepancy between KJ and EA are needed.

Table 3. Nitrogen concentrations of milk and urine and their SD when determined on a weight or volume basis $^{1}$

\begin{tabular}{|c|c|c|c|c|c|c|}
\hline Item & Weight & $\mathrm{SD}^{2}$ & Volume & $\mathrm{SD}$ & SEM & $P$-value \\
\hline \multicolumn{7}{|l|}{ Milk } \\
\hline Amount $^{3}$ & 31.0 & 0.39 & 30.0 & - & 0.08 & $<0.01$ \\
\hline $\mathrm{PD}^{4}$ & 2.72 & 1.68 & - & - & & \\
\hline $\mathrm{N}, \mathrm{g} /$ unit $^{5}$ & 5.70 & 0.32 & 5.88 & 0.36 & 0.098 & $<0.01$ \\
\hline $\mathrm{PD}$ & 0.71 & 0.63 & 2.84 & 1.73 & 0.376 & $<0.01$ \\
\hline \multicolumn{7}{|l|}{ Urine } \\
\hline Amount $^{3}$ & 30.1 & 0.48 & 30.0 & - & 0.10 & 0.72 \\
\hline PD & 4.22 & 2.15 & - & - & & \\
\hline $\mathrm{N}, \mathrm{g} /$ unit $^{5}$ & 9.19 & 2.45 & 9.21 & 2.26 & 0.709 & 0.64 \\
\hline $\mathrm{PD}$ & 0.91 & 0.94 & 4.53 & 2.71 & 0.586 & $<0.01$ \\
\hline
\end{tabular}

${ }^{1}$ Samples were collected from 12 cows, and each sample was assayed in duplicate.

${ }^{2}$ Average analytical result over the 12 samples.

${ }^{3}$ Weight of sample delivered (in $\mathrm{mg}$ ) or volume of sample delivered (in $\mu \mathrm{L}$ ).

${ }^{4}$ LSM of percentage deviations [(larger number - smaller number)/average $\times 100$ ] of duplicate analysis of each sample.

${ }^{5}$ Weight (in $\mathrm{g} / \mathrm{kg}$ ); volume (in $\mathrm{g} / \mathrm{L}$ ). 
Fecal $\mathrm{N}$ content decreased $(P<0.01)$ by $5.1 \%$ when samples were dried and analyzed by EA compared with wet KJ (Table 2). This could have been caused by analytical methods (KJ vs. EA) or drying of samples (i.e., $\mathrm{N}$ volatilization during drying; wet vs. LYO and OD). To assess the potential confounding effects of analytical methods (KJ vs. EA), lyophilized feces were further analyzed by KJ (see Table 2); a difference in $\mathrm{N}$ concentration $(P<0.01)$ was found between wet KJ and LYO-KJ, and no difference $(P=0.83)$ between LYOKJ and LYO-EA was observed. This clearly suggests that $\mathrm{N}$ losses from feces occurred during the drying process (LYO and OD). Studies on cattle feces have shown a decrease of 4.1 to $11.9 \%$ in fecal $\mathrm{N}$ when OD at a temperature of 60 to $100^{\circ} \mathrm{C}$ (Gallup and Hobbs, 1944; Colovos et al., 1957; Bratzler and Swift, 1959). Studies on effects of LYO on fecal N losses are limited. However, $\mathrm{N}$ losses of about $10 \%$ have been observed in our laboratory when fecal $\mathrm{N}$ was determined after LYO compared with wet (W. P. Weiss, unpublished data). To minimize $\mathrm{N}$ losses from feces during LYO and OD, acidification of feces when collected can be a potential option. Ribeiro et al. (2001) observed a significant decrease in $\mathrm{N}$ losses $(6.59$ vs. $5.92 \% \mathrm{~N}$ in fecal DM; $P$ $<0.05)$ from acidified feces compared with unacidified feces during $\mathrm{OD}$ at 55 and $100^{\circ} \mathrm{C}$.

Milk N concentration was $3.4 \%$ greater (5.70 vs. $5.50 \mathrm{~g} / \mathrm{kg} ; P<0.01)$ when dried and analyzed by EA compared with KJ (Table 2). However, drying method (LYO-EA vs. OD-EA) did not affect milk N concentration $(5.70$ vs. $5.69 \mathrm{~g} / \mathrm{kg} ; P=0.72)$. The same results were observed for urine samples. When urine was dried and analyzed for $\mathrm{N}$ using EA, urinary $\mathrm{N}$ concentration was greater (9.16 vs. $9.06 \mathrm{~g} / \mathrm{kg} ; P=0.02)$ compared with the analysis of fresh urine using KJ. However, urinary $\mathrm{N}$ concentration was not different $(P=0.98)$ between LYO and OD. This indicates that $\mathrm{N}$ content in milk and urine samples was affected by analytical method (i.e., KJ vs. EA) and not by drying (wet vs. drying) or drying method (LYO vs. OD). A comparison of milk and urine $\mathrm{N}$ concentration between KJ and EA is scarce. Lynch and Barbano (1999), however, observed that differences in milk $\mathrm{N}$ concentration were inconsistent when the 2 methods were compared. Recovery of milk $\mathrm{N}$ using KJ can be affected by errors in system operation (e.g., boiling time and temperature and digestion and distillation efficiency; see Lynch and Barbano, 1999). The difference in milk $\mathrm{N}$ between KJ and EA can increase with increasing sample $\mathrm{N}$ concentration (Etheridge et al., 1998; Thompson et al., 2002).

It is worth noting that when milk and urine $\mathrm{N}$ are analyzed using EA, concentrations should be on a mass basis (i.e., weighing out samples using a microbalance), not a volume basis (i.e., pipetting). Because the volume of milk and urine applied to tin capsules is small $(30 \mu \mathrm{L}$ in the current study), amounts of samples delivered into tin capsules are variable depending on pipetting style and consistency of pipetting between samples. In the current study (Table 3), one person carefully processed milk and urine samples on a weight and volume basis. The $\mathrm{N}$ concentration in milk was $5.70 \mathrm{~g} / \mathrm{kg}$ with 0.71 of $\mathrm{PD}$ and $5.88 \mathrm{~g} / \mathrm{L}$ with 2.84 of $\mathrm{PD}$ when determined on a weight and volume basis, respectively. Nitrogen concentration in urine was $9.19 \mathrm{~g} / \mathrm{kg}$ with 0.91 of PD and $9.21 \mathrm{~g} / \mathrm{L}$ with 4.53 of PD. This suggests that the $\mathrm{N}$ results were more precise when milk and urine $\mathrm{N}$ were determined by EA on a weight basis.

To our knowledge, this is the first study comparing $\mathrm{N}$ concentrations after LYO or OD of milk, urine, and feces of dairy cows. Oven drying of samples is much easier and faster compared with LYO. However, LYO has been a preferred method because OD has been assumed to potentially cause $\mathrm{N}$ losses, especially from urine or manure samples. In the current experiment, $\mathrm{N}$ concentrations of milk, urine, and feces determined by EA after OD or LYO did not differ $(P \geq 0.72)$. This suggests either that the degree of $\mathrm{N}$ losses during drying samples was the same between drying methods or that LYO and OD did not cause $\mathrm{N}$ losses from the samples. For feces, we observed a decrease in $\mathrm{N}$ concentration of about $5 \%$, probably via ammonia volatilization during sample drying. However, the degree of $\mathrm{N}$ losses during drying was similar between LYO and OD. In agreement, Jacobs et al. (2011) found no difference between OD and LYO in N concentration of pig feces. Another study by Ribeiro et al. (2001) found that N losses from poultry feces (colostomized birds) increased when drying temperature in the oven increased (i.e., 8 and $10 \%$ decreases in $\mathrm{N}$ content when dried at 55 and $100^{\circ} \mathrm{C}$, respectively) compared with $\mathrm{N}$ content determined from fresh samples without the drying process. Our results and the studies in the literature lead us to conclude that drying of fecal samples results in $\mathrm{N}$ losses to some extent, but the degree of losses is likely similar between LYO and OD.

No differences in $\mathrm{N}$ content in milk and urine after LYO or OD were observed, and $\mathrm{N}$ contents were actually greater for EA analysis after drying compared with wet KJ (discussed previously). This suggests that $\mathrm{N}$ losses from milk and urine during drying of samples did not occur or were minimal. Urea is the major $\mathrm{N}$ compound that is rapidly hydrolyzed to ammonia (under the presence of urease) for volatilization. Urea concentration in milk ranges from 5 to $15 \mathrm{mg} / \mathrm{dL}$ in lactating cows (Kauffman and St-Pierre, 2001), which is less than $0.5 \%$ in total milk $\mathrm{N}$. Therefore, no $\mathrm{N}$ losses 
in milk after drying were expected regardless of drying methods. However, cattle urine contains urea up to $90 \%$ of total N (Bussink and Oenema, 1998). Vaddella et al. (2010) observed ammonia emissions from fresh urine without contamination with feces in a laboratory incubation system, suggesting possible losses of $\mathrm{N}$ from urine. However, no losses of $\mathrm{N}$ from urine samples during drying in the current study were found and were likely because all the urine samples were acidified $(\mathrm{pH}$ $<3.0$ ), suggesting that acidification was successful for preventing $\mathrm{N}$ losses via ammonia volatilization from urine $\left(\mathrm{p} K_{\mathrm{a}}=9.0\right)$. In addition, the time required to dry urine samples in the oven was very short because only about $30 \mathrm{mg}$ of urine was applied for drying. Samples were kept in the oven for $1 \mathrm{~h}$ but appeared to be completely dry within 30 min (visual observation). Therefore, the lack of losses from urine during drying and the lack of a difference in urinary $\mathrm{N}$ content between $\mathrm{LYO}$ and OD could be attributed to acidification and the rapid drying process during OD.

According to PD (average $\pm \mathrm{SD} ; 2.41 \pm 0.40$ for KJ and $1.05 \pm 0.55$ for LYO- and OD-EA) from duplicate sample analysis, $\mathrm{N}$ determination by EA was generally more precise than that by KJ (except for concentrates and fecal N, which had similar PD between KJ and EA). This was expected because KJ has more steps to determine $\mathrm{N}$ concentration in samples compared with EA (i.e., acid digestion, distillation, and titration), generating analytical errors at each step. Although small PD was observed for EA in the current study, there is also concern about $\mathrm{N}$ determination by EA because a very small amount is applied for determination (about $5 \mathrm{mg}$ for solid samples and $30-60 \mathrm{mg}$ for liquid samples). Therefore, representative subsampling for applying to EA (e.g., pulverization and mixing for subsampling) is critical for $\mathrm{N}$ determination by EA. It is worth noting that although the difference in $\mathrm{N}$ concentration between KJ and EA that was found in the current study is in agreement with previous studies (i.e., greater $\mathrm{N}$ concentration when determined by EA vs. KJ) as discussed above, our results did not consider person-to-person and instrumental variations, which may need to be further examined (e.g., laboratory-tolaboratory variation).

Compared with KJ, EA resulted in greater $\mathrm{N}$ concentration in feed samples. Drying of feces before N analysis resulted in $\mathrm{N}$ losses from samples regardless of drying method (i.e., LYO and OD). For milk and urine, $\mathrm{N}$ contents were less when assayed by KJ compared with EA. However, drying methods of LYO and OD did not cause $\mathrm{N}$ losses from milk and acidified urine samples. Therefore, our suggestions for processing samples for $\mathrm{N}$ analysis are as follows: (1) various samples collected from cows should be analyzed consistently by a single analytical method (i.e., KJ or EA) due to the discrepancy in $\mathrm{N}$ concentration between KJ and EA (feeds, feces, milk, and urine); (2) when $\mathrm{N}$ is determined by EA, OD of milk and urine can replace LYO for $\mathrm{N}$ determination; and (3) for OD, urine should be acidified immediately when collected and a small weight of urine (30 mg) should be rapidly oven dried (30-60 min), which can help prevent $\mathrm{N}$ loss. In addition, acidified and undiluted urine samples kept at $-20^{\circ} \mathrm{C}$ need to be analyzed within $90 \mathrm{~d}$ of collection.

\section{ACKNOWLEDGMENTS}

The authors thank P. A. Dieter (The Ohio State University, Wooster) and D. J. Wyatt (The Ohio State University, Wooster) for assistance with sample collection and laboratory assays. Research was supported by Department of Animal Sciences, The Ohio State University, and partially funded from Hatch funds administered by US Department of Agriculture and state and federal funds appropriated to the Ohio Agricultural Research and Development Center, The Ohio State University.

\section{REFERENCES}

Albasan, H., J. P. Lulich, C. A. Osborne, C. Lekcharoensuk, L. K. Ulrich, and K. A. Carpenter. 2003. Effects of storage time and temperature on $\mathrm{pH}$, specific gravity, and crystal formation in urine samples from dogs and cats. J. Am. Vet. Med. Assoc. 222:176-179.

Alomar, D., R. Fuchslocher, and S. Stockebrand. 1999. Effects of ovenor freeze-drying on chemical composition and NIR spectra of pasture silage. Anim. Feed Sci. Technol. 80:309-319.

AOAC International. 2000. Official Methods of Analysis. Vol. 1 and 2. 17th ed. AOAC International, Gaithersburg, MD.

Bratzler, J., and R. Swift. 1959. A comparison of nitrogen and energy determinations on fresh and oven-air dried cattle feces. J. Dairy Sci. 42:686-691.

Bussink, D., and O. Oenema. 1998. Ammonia volatilization from dairy farming systems in temperate areas: A review. Nutr. Cycl. Agroecosyst. 51:19-33.

Colovos, N. F., H. A. Keener, and H. A. Davis. 1957. Errors in drying silage and feces for protein and energy determinations: Improved procedures. J. Dairy Sci. 40:173-179.

Deinum, B., and A. Maassen. 1994. Effects of drying temperature on chemical composition and in vitro digestibility of forages. Anim. Feed Sci. Technol. 46:75-86.

Etheridge, R., G. Pesti, and E. Foster. 1998. A comparison of nitrogen values obtained utilizing the Kjeldahl nitrogen and Dumas combustion methodologies (Leco CNS 2000) on samples typical of an animal nutrition analytical laboratory. Anim. Feed Sci. Technol. $73: 21-28$.

Gallup, W. D., and C. S. Hobbs. 1944. The desiccation and analysis of feces in digestion experiments with steers. J. Anim. Sci. 3:326-332.

Heberer, J. A., F. E. Below, and R. H. Hageman. 1985. Drying method effect on leaf chemical constituents of four crop species. Crop Sci. 25:1117-1119.

Hristov, A. N., M. Hanigan, A. Cole, R. Todd, T. A. McAllister, P. M. Ndegwa, and A. Rotz. 2011. Review: Ammonia emissions from dairy farms and beef feedlots. Can. J. Anim. Sci. 91:1-35. 
Jacobs, B. M., J. F. Patience, W. A. Dozier 3rd, K. J. Stalder, and B. J. Kerr. 2011. Effects of drying methods on nitrogen and energy concentrations in pig feces and urine, and poultry excreta. J. Anim. Sci. 89:2624-2630.

Jung, S., D. A. Rickert, N. A. Deak, E. D. Aldin, J. Recknor, L. A. Johnson, and P. A. Murphy. 2003. Comparison of Kjeldahl and Dumas methods for determining protein contents of soybean products. J. Am. Oil Chem. Soc. 80:1169-1173.

Kauffman, A. J., and N. R. St-Pierre. 2001. The relationship of milk urea nitrogen to urine nitrogen excretion in Holstein and Jersey cows. J. Dairy Sci. 84:2284-2294.

Lynch, J. M., and D. M. Barbano. 1999. Kjeldahl nitrogen analysis as a reference method for protein determination in dairy products. J. AOAC Int. 82:1389-1398.

Pelletier, S., G. F. Tremblay, A. Bertrand, G. Bélanger, Y. Castonguay, and R. Michaud. 2010. Drying procedures affect non-structural carbohydrates and other nutritive value attributes in forage samples. Anim. Feed Sci. Technol. 157:139-150.

Ribeiro, A. M. L., A. M. Penz, T. K. Belay, and R. G. Teeter. 2001. Comparison of different drying techniques for nitrogen analysis of poultry excreta, feces, and tissue. J. Appl. Poult. Res. 10:21-23.

Simonne, A. H., E. H. Simonne, R. R. Eitenmiller, H. A. Mills, and C. P. Cresman. 1997. Could the Dumas method replace the Kjeldahl digestion for nitrogen and crude protein determinations in foods? J. Sci. Food Agric. 73:39-45.

Simonne, E. H., C. E. Harris, and H. A. Mills. 1998. Does the nitrate fraction account for differences between Dumas-N and Kjeldahl-N values in vegetable leaves? J. Plant Nutr. 21:2527-2534.

Tebbe, A. W., D. J. Wyatt, and W. P. Weiss. 2018. Effects of magnesium source and monensin on nutrient digestibility and mineral balance in lactating dairy cows. J. Dairy Sci. 101:1152-1163.

Thiex, N. 2009. Evaluation of analytical methods for the determination of moisture, crude protein, crude fat, and crude fiber in distillers dried grains with solubles. J. AOAC Int. 92:61-73.

Thompson, M., L. Owen, K. Wilkinson, R. Wood, and A. Damant. 2002. A comparison of the Kjeldahl and Dumas methods for the determination of protein in foods, using data from a proficiency testing scheme. Analyst 127:1666-1668.

Vaddella, V. K., P. M. Ndegwa, H. S. Joo, and J. L. Ullman. 2010. Impact of separating dairy cattle excretions on ammonia emissions. J. Environ. Qual. 39:1807-1812.

Weiss, W. P., N. R. St-Pierre, and L. B. Willett. 2009. Varying forage type, metabolizable protein concentration, and carbohydrate source affects manure excretion, manure ammonia, and nitrogen metabolism of dairy cows. J. Dairy Sci. 92:5607-5619. 